\title{
Mestrado Profissional: contribuições para o avanço das pesquisas e discussões sobre educação e ensino
}

\section{EDITORIAL}

Os mestrados profissionais surgiram tardiamente no campo da educação brasileira e se ampliaram na última década cercados de questionamentos em relação à qualidade das pesquisas produzidas em seus programas. Após 10 anos acompanhando essa evolução cabe lançar um olhar sobre a produção acadêmica construída, revelando a qualidade e a responsabilidade com as quais as pesquisas têm sido realizadas.

Entendemos oportuno revelar esses saberes construídos dentro da profissão, que compõem um conjunto de experiências teoricamente fundamentadas, que servem tanto de alicerce para uma reflexão crítica sobre a realidade quanto de projeção para o desenvolvimento profissional de sujeitos críticos e criativos.

Este dossiê vem somar a outros já publicados e pretende trazer à tona produções e discussões sobre os mestrados profissionais que envolvem a educação e o ensino. Entende-se que as publicações de diversas experiências e pesquisas sobre o tema podem, além de fortalecer os programas, socializar produções, resultados e discussões sobre problemas reais encontrados no cotidiano daqueles que vivem a educação e o ensino. Foi organizado $m$ conjunto por integrantes de diferentes universidades, Marli E. D. A. de André (PUC-SP), Ana Maria Gimenes Corrêa Calil (UNITAU) e Douglas da Silva Tinti (UFOP).
Está composto por 10 artigos de diferentes universidades e localidades do país, que trazem em seu bojo aspectos sobre as propostas acadêmicas e as diferentes matrizes curriculares dos cursos de Mestrado Profissional e sua articulação com o conhecimento específico; análise de produtos educacionais elaborados a partir das dissertações produzidas em dois Programas de Pós-Graduação na modalidade de Mestrado Profissional e outras experiências realizadas em diferentes disciplinas dos cursos. Alguns artigos também dão voz aos egressos a fim de colherem informações sobre as suas impressões dos cursos e seu desenvolvimento profissional após a conclusão do mestrado profissional.

Dessa forma, esse dossiê tem o propósito de contribuir para firmar o campo dos mestrados profissionais e revelar alguns estudos organicamente imbricados às práticas de educadores que vêm construindo saberes no cotidiano das suas escolas e sistemas de ensino. Agradecemos a parceria e a confiança de todos os autores que contribuíram com essa edição, bem como, os pareceristas sem os quais também não seria possível publicarmos. Desejamos a todos boa leitura!

Ana Maria Gimenes Corrêa Calil Douglas da Silva Tinti Marli André Organizadores 